\title{
Erratum to: Weakly supervised learning of biomedical information extraction from curated data
}

Suvir Jain ${ }^{1 \dagger}$, Kashyap R. Tumkur ${ }^{1 \dagger}$, Tsung-Ting Kuo ${ }^{2}$, Shitij Bhargava ${ }^{1}$, Gordon Lin ${ }^{1}$ and Chun-Nan Hsu ${ }^{2 *}$

After publication of this article [1] it has been found that the name of the second author's last name had been accidentally left out. The correct name is Kashyap R. Tumkur which has been herewith corrected in this erratum.

\section{Author details}

'Department of Computer Science and Engineering, Jacobs School of Engineering, University of California, 9500 Gilman Drive, La Jolla, San Diego 92093, USA. ${ }^{2}$ Department of Biomedical Informatics, School of Medicine,

University of California, 9500 Gilman Drive, La Jolla, San Diego 92093, USA.

Published: 11 February 2016

\section{Reference}

1. Jain S, Tumkur KR, Kuo T-T, Bhargava S, Lin G, Hsu C-N. Weakly supervised learning of biomedical information extraction from curated data. BMC Bioinformatics. 2016;17(Suppl 1):1.

\footnotetext{
* Correspondence: chunnan@ucsd.edu

${ }^{\dagger}$ Equal contributors

${ }^{2}$ Department of Biomedical Informatics, School of Medicine, University of California, 9500 Gilman Drive, La Jolla, San Diego 92093, USA
}

\section{Submit your next manuscript to BioMed Central and take full advantage of: \\ - Convenient online submission \\ - Thorough peer review \\ - No space constraints or color figure charges \\ - Immediate publication on acceptance \\ - Inclusion in PubMed, CAS, Scopus and Google Scholar \\ - Research which is freely available for redistribution

